Pesq. Vet. Bras. 38(1):147-153, janeiro 2018

\title{
Bovine central nervous system development ${ }^{\mathbf{1}}$
}

\author{
Amanda O. Ferreira2*, Bruno G. Vasconcelos ${ }^{3}$, Phelipe O. Favaron², Amilton C. Santos ${ }^{2}$, \\ Rafael M. Leandro ${ }^{2}$, Flávia T.V. Pereira ${ }^{4}$, Durvanei A. Maria ${ }^{2}$ and Maria Angélica Miglino ${ }^{2}$
}

ABSTRACT.- Ferreira A.O., Vasconcelos B.G., Favaron P.O., Santos A.C., Leandro R.M., Pereira F.T.V., Maria D.A. \& Miglino M.A. 2018. Bovine central nervous system development. Pesquisa Veterinária Brasileira 38(1):147-153. Setor de Anatomia dos Animais Domésticos e Silvestres, Faculdade de Medicina Veterinária e Zootecnia, Universidade de São Paulo, Av. Prof. Dr. Orlando Marques de Paiva 87, São Paulo, SP 05508-030, Brasil. E-mail: olivotti@usp.br

Central nervous system (CNS) development researches are extremely important to the most common congenital disorders and organogenesis comprehension. However, few studies show the entire developmental process during the critical period. Present research can provide data to new researches related to normal development and abnormalities and changes that occur along the CNS organogenesis, especially nowadays with the need for preliminary studies in animal models, which could be used for experimental research on the influence of viruses, such as the influence of Zika virus on the development of the neural system and its correlation with microcephaly in human newborns. Then, present study describes CNS organogenesis in cattle according to microscopic and macroscopic aspects, identifying structures and correlating to gestational period. Fourteen embryos and nine bovine fetuses at different ages were collected and analyzed. All individuals were measured in order to detect the gestational period. Bovine embryo at 17 days age has its neural tube, cranial neuropore, caudal neuropore and somites developed. After 24 days of development, were observed in cranial part of neural tube five encephalic vesicles denominated: telencephalon, diencephalon, mesencephalon, metencephalon and myelencephalon. In addition, the caudal part of neural tube was identified with the primitive spinal cord. The primordial CNS differentiation occurred from 90 to 110 days. The five encephalic vesicles, primordial spinal cord and the cavities: third ventricule, mesencephalic aqueduct, fourth ventricle and central canal in spinal cord were observed. With 90 days, the main structures were identified: (1) cerebral hemispheres, corpus callosum and fornix, of the telencephalon; (2) interthalamic adhesion, thalamus, hypothalamus and epythalamus (glandula pinealis), of the diencephalon; (3) cerebral peduncles and quadruplets bodies, of the mesencephalon; (4) pons and cerebellum, of the metencephalon; (5) medulla oblongata or bulb, of the myelencephalon; and (6) spinal cord, of the primitive spinal cord. After 110 days of gestation, the five encephalic vesicles and its structures were completely developed. It was noted the presence of the spinal cord with the cervicothoracic and lumbossacral intumescences. In summary, the results describes the formation of the neural tube from the neural plate of the ectoderm, the encephalic vesicles derived from the neural tube and subsequent structural and cavities subdivisions, thus representing the complete embryology of the central nervous system.

INDEX TERMS: Bovine central nervous system, encephalon, encephalic vesicles, CNS, ontogeny, spinal cord.

RESUMO.- [Desenvolvimento do sistema nervoso central de bovinos.] Os estudos que descrevem o desenvolvimento do sistema nervoso central (SNC) são de suma

\footnotetext{
${ }^{1}$ Received on April 24, 2016.

Accepted for publication on November 18, 2016.

${ }^{2}$ Faculdade de Medicina Veterinária e Zootecnia, Universidade de São Paulo, Av. Prof. Dr. Orlando Marques de Paiva 87, São Paulo, SP 05508-270, Brazil. E-mails: phelipe.favaron@yahoo.com.br, amiltonsantoss@usp.br, rafael.magdanelo@gmail.com,durvanei@usp.br; miglino@usp.br; *Corresponding author: olivotti@usp.br
}

importância para compreensão da organogênese e identificação dos prováveis eventos que resultam em malformações congênitas. Estes dados podem subsidiar novas

\footnotetext{
${ }^{3}$ Instituto de Ciências Agrárias, Universidade Federal dos Vales Jequitinhonha e Mucuri, Av. Vereador João Narciso 1380, Bairro Cachoeira, Unaí, MG 38610-000, Brazil. E-mail: vasconcelosufvjm@gmail.com

4 Universidade Estadual Paulista "Júlio de Mesquita Filho" (Unesp), Campus Dracena, Rodovia Comandante João Ribeiro de Barros Km 651, Bairro das Antas, Dracena, SP 17900-000, Brazil. E-mail: fverechia@dracena.unesp.br
} 
pesquisas relacionadas ao desenvolvimento normal, e interpretação de malformações e alterações que ocorrem ao longo da organogênese do SNC, considerando neste momento a necessidade de estudos preliminares em modelos animais, os quais poderiam ser utilizados para pesquisas experimentais sobre a influência de agentes infecciosos como o Zika vírus, no desenvolvimento do sistema nervoso e suas relações com a microcefalia em humanos recém-nascidos. 0 presente estudo teve como objetivo descrever os aspectos morfológicos macro e microscópicos da organogênese do SNC de bovinos, buscando correlacionar os achados morfológicos com a idade gestacional. Todos os animais foram mensurados para detectar o período gestacional. Foram coletados e analisados 14 embriões e nove fetos de bovinos de diferentes idades gestacionais. No embrião bovino a partir do décimo sétimo dia de gestação, encontra-se a formação do tubo neural, o neuroporo cranial e neuroporo caudal, e formação dos somitos. Após 24 dias de desenvolvimento, são observadas na parte cranial do tubo neural cinco vesículas encefálicas denominadas: telencéfalo, diencéfalo, mesencéfalo, metencéfalo e mielencéfalo; e na parte caudal do tubo neural, encontra-se a medula espinhal primitiva. Entre 90 a 110 dias de gestação, observa-se a total diferenciação das cinco vesículas do SNC. Com 90 dias, são identificas as principais estruturas: (1) do telencéfalo, os hemisférios cerebrais, corpo caloso e fórnix; (2) do diencéfalo, a aderência intertalâmica, tálamo, hipotálamo e epitálamo (glândula pineal); (3) do mesencéfalo, os pedúnculos cerebrais e os corpos quadrigêmios; (4) do metencéfalo, a ponte e o cerebelo; (5) do mielencéfalo, a medula oblonga (ou bulbo); e (6) da medula espinhal primitiva, a medula espinhal. Após 110 dias, as cinco vesículas encefálicas e as suas subdivisões se encontram completamente desenvolvidas. Notou-se a presença da medula espinhal com as intumescências cervicotorácica e lombossacral. Em resumo, os resultados demonstram a formação do tubo neural a partir da placa neural do ectoderma, as vesículas encefálicas provenientes do tubo neural e posteriormente as subdivisões das estruturas e das cavidades, que representam a completa embriologia do sistema nervoso central.

TERMOS DE INDEXAÇÃO: Sistema nervoso central, bovinos, encéfalo, medula espinhal, ontogenia, SNC, vesículas encefálicas.

\section{INTRODUCTION}

The largest exporters of beef in the world are Brazil, India, Australia and United States of America (USA). Since 1995, Brazil has increased beef production and its global market participation. Between 1995 and 2012, beef global exports increased $47 \%$ while the Brazilian exports increased 568\%. However, from 1995 to 2002 exporters of beef faced a difficult period. Bovine spongiform encephalopathy or "mad cow" crisis caused the reduction of exports in the same period (Melz et al. 2014).

Rissi et al. (2010) found that the main diseases of the central nervous system (CNS) diagnosed in cattle in Brazil were rabies, hepatic encephalopathy due to liver failure by ingestion of Senecio spp., bovine herpesvirus meningoencephalitis, cerebral babesiosis, Solanum fastigiatum poisoning, bluetongue and the polioencephalomalacia.
In addition, in early third of the gestation embryonic mortality ratio in cattle is high. In the embryonic period (from 15th to 45th day of gestation) occurs the formation of the main tissues, organs and systems, setting out the main external characteristics of the body. The fetal period runs from the day 45 , which is the period that the formation of the external features of the body occurs (Maddox-Hyttel et al. 2007).

To improve the quality and efficiency of the production of cattle and, in particular, to avoid losing by neurological diseases, it becomes necessary greater knowledge related to CNS and its embryonic development, which is the period that makes it possible to raise important results that support the diagnosis of diseases and congenital abnormalities. In the CNS ontogeny process, the neurulation involves multiple morphological coordinated events, resulting in the conversion of neural plate in the neural tube and later its subdivisions. Therefore, as results it generates neural tube defects and severe CNS abnormalities (Greene \& Copp 2009).

Embryonic CNS development studies are extremely relevant to the organogenesis and its congenital abnormalities probable causes comprehension (Cagnoto et al. 2009). In addition, the greatest susceptibility to teratogens is the embryonic period (Evans \& Sack 1973), the stage in which the primitive germ layers form the major organs. Every organ has a critical stage of development, featuring an ordered sequence of biochemical processes involved, which are integrated by several genes, which lead to growth and its differentiation (Arthur 1979, Moore \& Persaud 2004, Synowatz 2010, Silva et al. 2016).

CNS researches are extremely important to the most common congenital disorders and organogenesis comprehension (Silva et al. 2016). However, few studies show the entire developmental process during the critical period. Present research can provide data to new researches related to normal development and abnormalities and changes that occur along the CNS organogenesis, especially nowadays with the need for preliminary studies in animal models, which could be used for experimental research on the influence of viruses, such as the influence of Zika virus (Cugola et al. 2016) on the development of the neural system and its correlation with microcephaly in human newborns.

Whereas the insufficiency of studies completely covering the CNS organogenesis during its critical developmental period, the aim of the present study was to describe macroscopically and microscopically the CNS organogenesis, identifying the structures and correlating with gestational age in order to provide data for better understanding yours development and for future pathological and pharmacological studies.

\section{MATERIALS AND METHODS}

For this study 23 uterus of pregnant Bos indicus cattle in different gestational ages from slaughterhouses in Andradina SP and Inhumas GO were collected. All laboratory procedures followed the precepts of the Brazilian College of Animal Experimentation (COBEA).

Immediately after collection of uterus, the fetuses and embryos were extracted. Then, a total of 14 embryos and nine fetuses were collected. 
Embryos were fixed by injection of $10 \%$ formaldehyde solution. For fetuses, formaldehyde was channeled by the umbilical vein and umbilical arteries ligation. Subsequently it was performed new ligature in umbilical vein and umbilical arteries and the pieces were stored in the same solution for 48 hours.

To verify the animals macroscopic analysis it was performed the Crown-rump (CR) measurement that is the distance of the nuchal crest until the last sacral vertebra. The CR measurement was taken by using digital MITUTOYO ${ }^{\circledR}$ pachymeter. Photography of embryo and fetuses were taken with Nikon digital camera model D40x for further description.

Embryos gestational age was estimated in days according to the previous studies (Winters et al. 1942, Evans \& Sacks 1973, Noden \& Lahunta 1990). In fetuses over 1.5 months of gestation it was used the formula $\mathrm{X}=\mathrm{M}(\mathrm{M}+2)$, where $\mathrm{X}$ is the $\mathrm{CR}$ measurement in centimeters and $\mathrm{M}$ the gestational age in months (Rexroad et al. 1974).

Microstructural analysis of the CNS, embryos and fetuses were processed in increasing ethanol series (70 to 100\%) for dehydration and stained in xylene, by using conventional procedure for subsequent inclusion in paraffin. So, tissue sections were obtained with $5 \mu \mathrm{m}$ of thickness in semi-automatic microtome. Then paraffin was removed from the samples, stained in hematoxylin and eosin (HE), analyzed and microphotography were taken (Olympus BX4160 Microscope coupled to Axio camera CAM HRc) with Zeiss KS400 software.

\section{RESULTS}

According to the data obtained from measurements of Crown-rump, specimens of cattle embryos and fetuses exhibited different sizes as observed in the Table 1.

Table 1. Estimated gestational age following Crown-rump (CR) according to Evans \& Sack (1973) in bovine embryos and fetuses

\begin{tabular}{lccc}
\hline $\begin{array}{c}\text { Estimated } \\
\text { gestational Age }\end{array}$ & Identification & CR (mm) & $\begin{array}{c}\text { Estimated Age } \\
\text { (days) }\end{array}$ \\
\hline Embryo & E1 & 8,0 & 17 \\
& E2 & 9,09 & 19 \\
E3 & 14,12 & 24 \\
E4 & 15,15 & 29 \\
E5 & 18,1 & 35 \\
E6 & 18,35 & 36 \\
E7 & 19,46 & 37 \\
E8 & 20,41 & 38 \\
E9 & 22,73 & 39 \\
E10 & 24,8 & 41 \\
E11 & 25,9 & 43 \\
E12 & 27 & 45 \\
F1 & 48 & 50 \\
F2 & 63,2 & 65 \\
F3 & 111,19 & 90 \\
F4 & 125,8 & 100 \\
F5 & 203 & 110 \\
F6 & 216 & 120 \\
F7 & 261 & 135 \\
F7 & 324 & 160 \\
F8 & 425 & 180 \\
& & &
\end{tabular}

\section{Development of the central nervous system of embryos from 17 to 35 days of gestation}

Histological analyses from bovine embryos between 17 and 19 days showed the formation of the neural tube, the cranial and caudal neuropores, amniotic membrane and the first formation of somites. Microscopically, were observed in bovine embryos from 24, 29 and 35 days of gestation, the five encephalic vesicles respectively: telencephalon, diencephalon, mesencephalon, metencephalon and myelencephalon. It was noted also the presence of the choroid plexus in the cavities and primitive spinal cord, relating to myelencephalon rostral (Fig.1).

\section{Central nervous system development of embryos from 36 to 45 days of gestation}

It was possible to observe, microscopically, the encephalon, central canal of primitive spinal cord and choroid
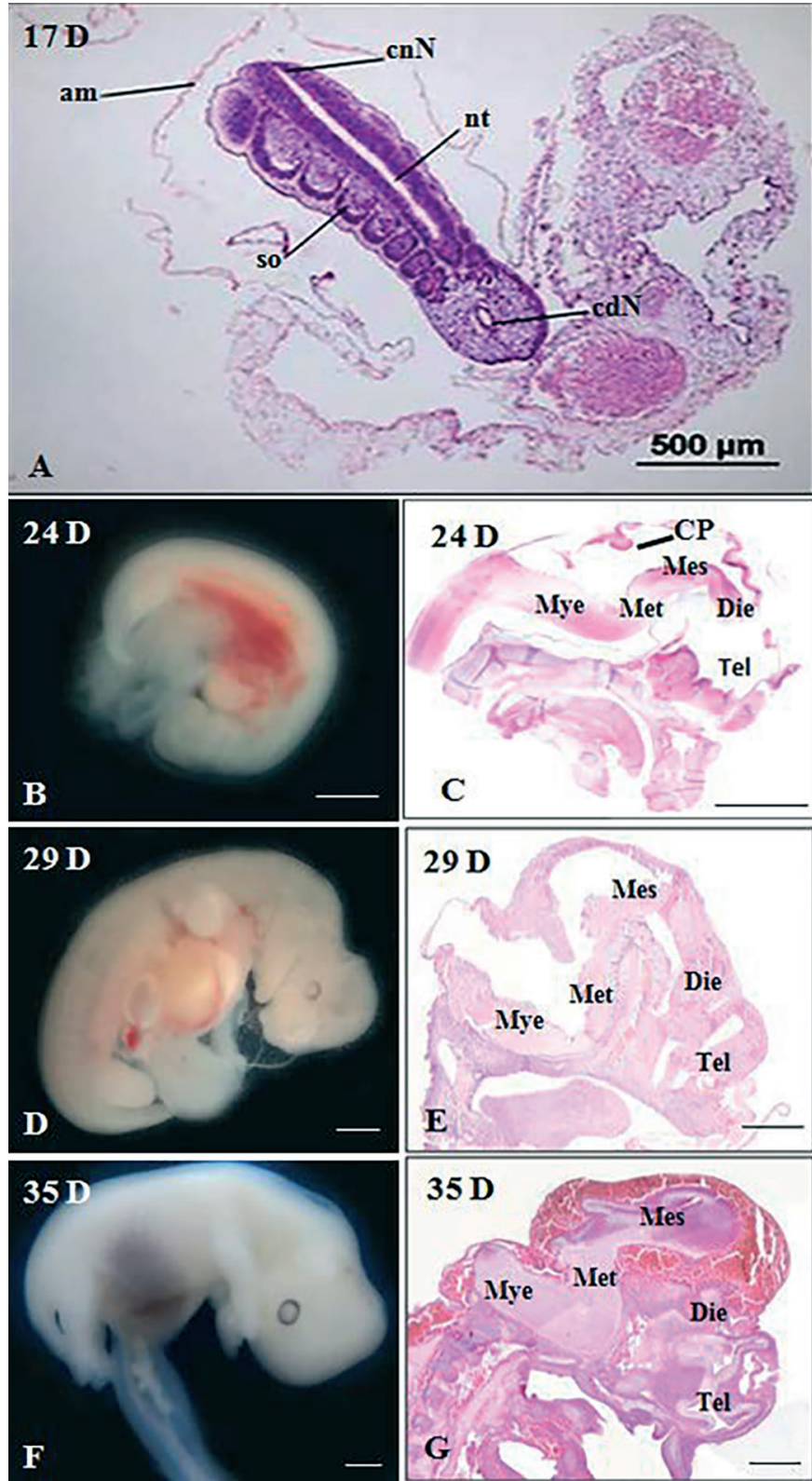

Fig.1. Bovine embryos at 17, 24, 29 and 35 days of gestation. (A) Neural tube (nt), cranial neuropore $(\mathrm{crN})$, caudal neuropore $(\mathrm{cdN})$, amniotic membrane (am) and somites (so). (B,D,F) Bovine embryos. Bars $1 \mathrm{~mm}$. (C,E,G) Embryonic neural tube development with their primary divisions and subdivisions, the telencephalon (Tel), diencephalon (Die), mesencephalon (Mes), metencephalon (Met) and myelencephalon (Mye) respectively; the presence of the early development of the choroid plexus (CP). HE, Bars 500um. 
plexus formation, in bovine embryos with 36,37 and 38 days of gestation. In the embryos with 39 days, it was observed a greater development of cavities of neural tube and the primitive spinal cord. At 41 days, embryo showed the presence of hyaline cartilage and primitive spinal cord. At 43 days, it was observed the presence of choroid plexus, detailing its simple cubic epithelium, which is composed by vascular membrane folds pia mater and the cerebellum. It was observed in 45-days embryo the defined primitive spinal cord, with the presence of circulating blood cells (Fig.2).

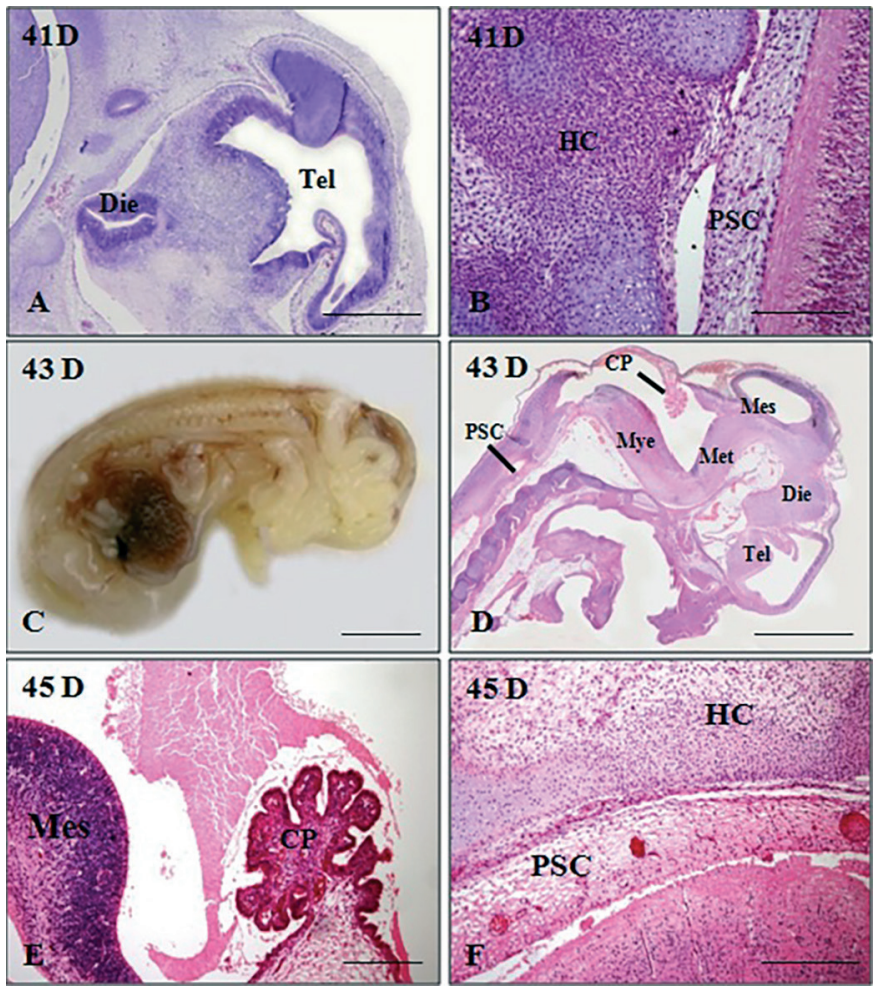

Fig.2. Bovine embryos at 41, 43 and 45 days of gestation. (A) Telencephalon (Tel) and diencephalon (Die). Bar 1mm. (B) Hyaline cartilage (HC) and primitive spinal cord (PSC). Bar $200 \mu \mathrm{m}$. (C,D) Telencephalon (Tel), diencephalon (Die), mesencephalon (Mes), metencephalon (Met), myelencephalon (Mye), primitive spinal cord (PSC) and choroid plexus (CP). Bars $5 \mathrm{~mm}$ and $500 \mu \mathrm{m}$. (E,F) Mesencephalon (Mes), choroid plexus (CP), primitive spinal cord (PSC) and hyaline cartilage (HC). HE, Bars $200 \mu \mathrm{m}$ and $500 \mu \mathrm{m}$.

\section{Development and organization of the encephalon of fe- tuses from 65 to 180 days of gestation}

Five encephalic vesicles were observed in a 65 days fetus: telencephalon, diencephalon, mesencephalon, metencephalon and myelencephalon, highlighting the primitive spinal cord (Fig.3). Microscopically were observed the meningeal layers: dura mater, arachnoid mater and pia mater. Dura mater was the thickest and external layer of the three membranes. It is often referenced as pachymeninx. The encephalic part of the dura mater was continuous with the spinal part of the dura mater at the foramen magnum. However, the dura mater of neurocranium consisted of two layers fused: an external periosteal layer called endosteum and an inner meningeal layer, while the spinal dura mater
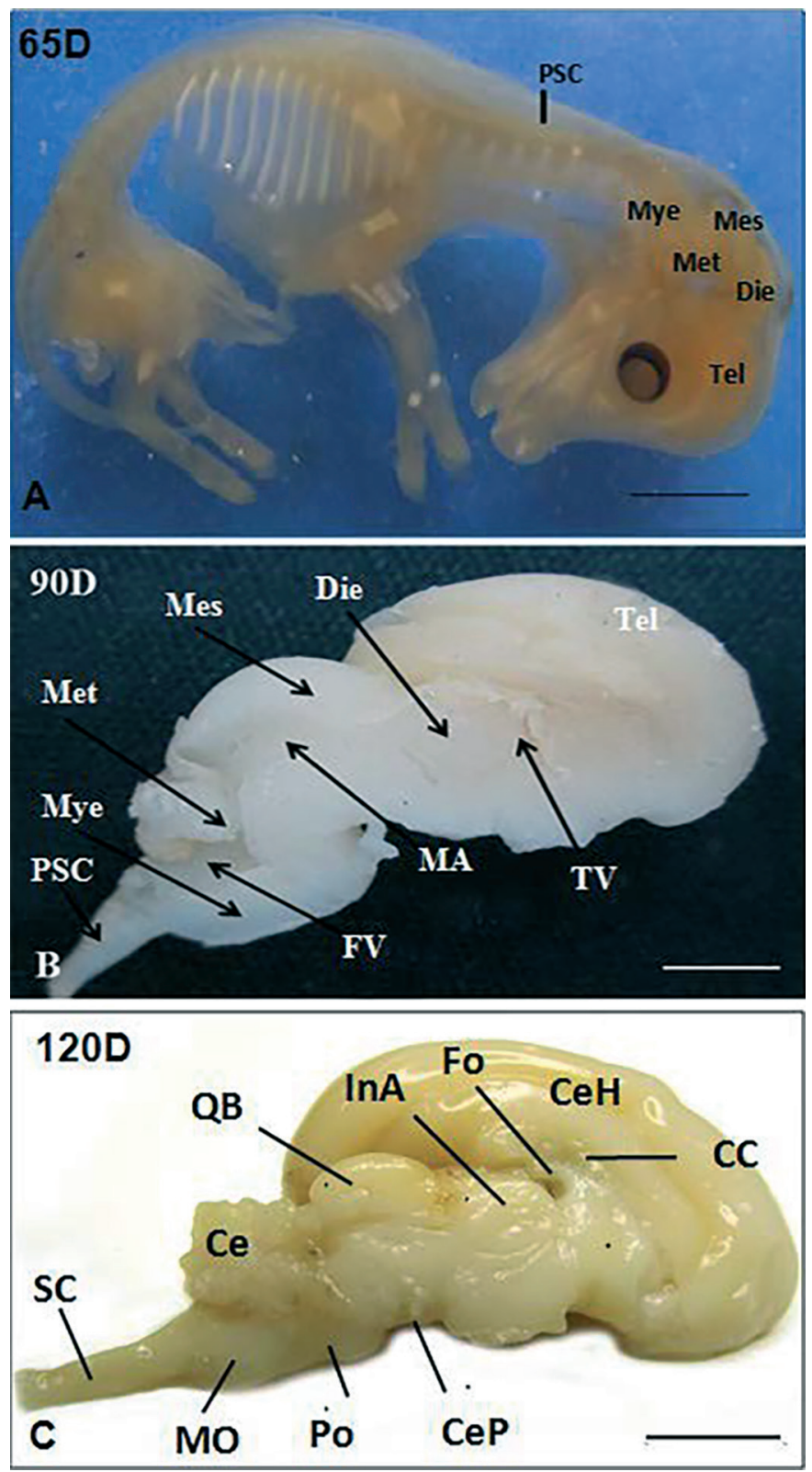

Fig.3. Macrophotography of 65, 90 and 120 days of gestation bovine fetus. (A) Telencephalon (Tel), diencephalon (Die), mesencephalon (Mes), metencephalon (Met), myeloencephalon (Mye) and primitive spinal cord (PSC). Bar 10mm. (B) Telencephalon (Tel), diencephalon (Die), mesencephalon (Mes), metencephalon (Met), myelencephalon (Mye), primitive spinal cord (PSC) and cavities: third ventricle (TV), mesencephalic aqueduct (MA) and fourth ventricle (FV). Bar $5 \mathrm{~mm}$. (C) Key derived from the regions: cerebral hemispheres (CeH), corpus callosum (CC) and fornix (Fo), of the telencephalon; interthalamic adhesion (InA), of the diencephalon; cerebral peduncle (CeP) and quadrupletes bodies (QB), of the mesencephalon; pons (Po) and cerebellum (Ce), of the metencephalon; the medulla oblongata (MO) or bulb, of the myelencephalon; and the spinal cord (SC). Bar 10mm.

possessed only one layer. The arachnoid mater performed as a meningeal layer found immediately internally to the dura mater. It was characterized as a delicate and avascular diaphragm separated from the dura mater by the subdural space, which is only a potential space produced by trauma. 


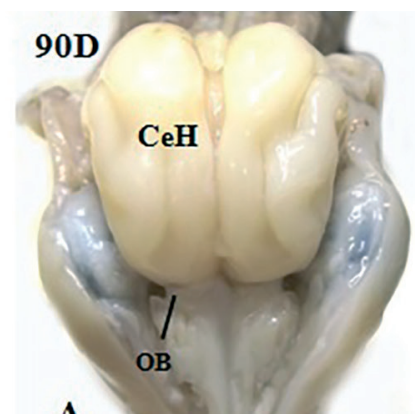

A
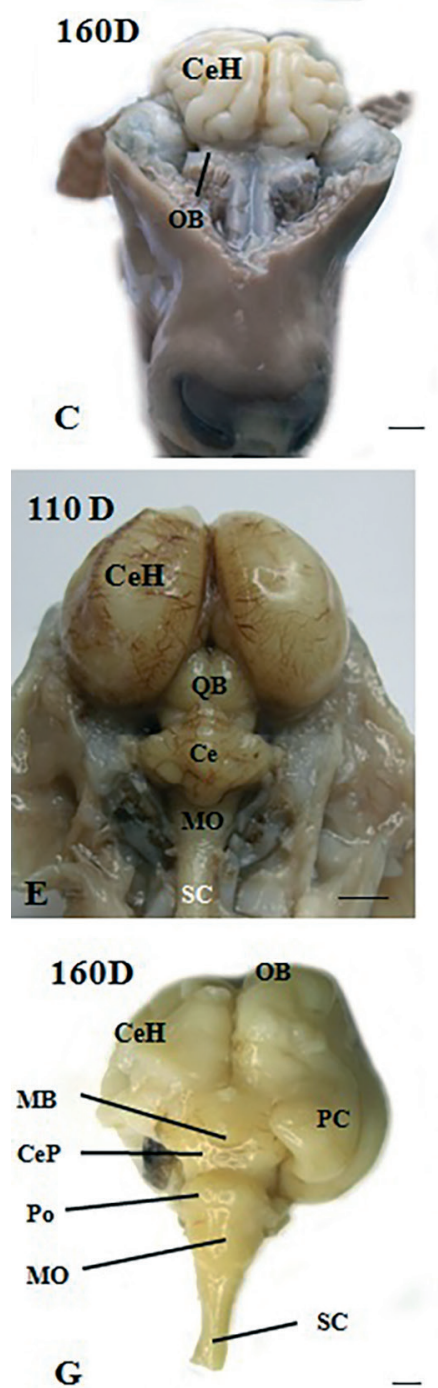
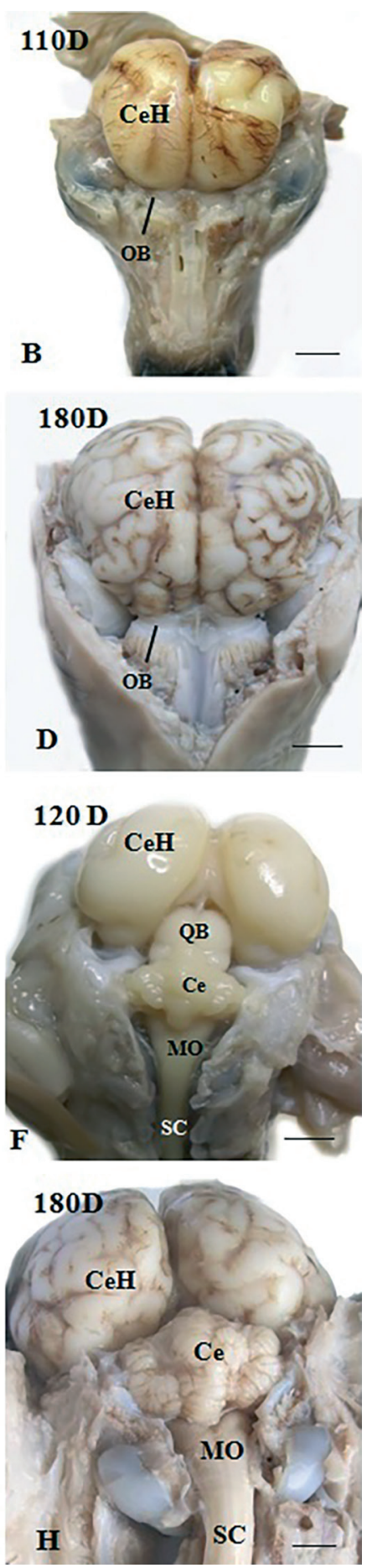

Fig.4. Rostral face in bovine fetuses. (A,B) At 90, 110 days: cerebral hemispheres $(\mathrm{CeH})$, and olfactory bulb (OB). (C,D) At 160, 180 days: cerebral hemispheres $(\mathrm{CeH})$ and olfactory bulb (OB). [E] and [F] 110, 120 days in caudal face: cerebral hemispheres $(\mathrm{CeH})$, quadruplets bodies (QB), cerebellum (Ce), medulla oblongata (MO) or bulb and spinal cord (SC). [G] 160 days in ventral face: olfactory bulb (OB), cerebral hemispheres $(\mathrm{CeH})$, piriform cortex (PC), mammillary body (MB), cerebral peduncle ( $\mathrm{CeP}$ ), pons (Po), medulla oblongata (MO) or bulb and spinal cord (SC). [H] 180 days in caudal face: cerebral hemisphere $(\mathrm{CeH})$, cerebellum (Ce), medulla oblongata (MO) or bulb and spinal cord (SC). Bars $1 \mathrm{~cm}$.
The arachnoid mater was separated from the innermost layer of the meninges, the pia mater, subarachnoid space that contains cerebrospinal fluid (CSF). The two innermost meninges are embryologically originates from a single layer, the leptomeninx. In the fetus of 90 days there was a differentiation of primary CNS regions in which resembles the morphology of its main structures, but was not yet possible to tell them apart in this period.

In 90-days bovine fetuses, it was observed that there was a differentiation of primary CNS regions in which resembled the morphology of its major subdivisions, but it was not possible to distinguish them. Thus, viewed the telencephalon, diencephalon, mesencephalon, metencephalon, myelencephalon, primitive spinal cord and encephalic cavities: lateral ventricles, third ventricle, mesencephalic aqueduct and fourth ventricle. The main structures were: (1) of the cerebral hemispheres, corpus callosum and fornix, of the telencephalon; (2) of the interthalamic adhesion, thalamus, hypothalamus and epythalamus (glandula pinealis), of the diencephalon; (3) cerebral peduncles and quadruplets bodies, of the mesencephalon; (4) pons and cerebellum, of the metencephalon; (5) the medulla oblongata or bulb, of the myelencephalon; and (6) the spinal cord, of the primitive spinal cord. In this period also showed the gestational five encephalic vesicles, but more developed than those found in fetuses at 65 days (Fig.4).

As observed, shortly after the 43 days of gestation, there was the last distinction of encephalic vesicles, the telencephalon, diencephalon, mesencephalon, metencephalon and myelencephalon. Later, from the $90^{\text {th }}$ day the formation of its main structures was observed.

\section{Spinal Cord development in embryos and fetuses from 43 to 180 days}

In fetuses with respective ages 110,120 and 160 days of gestation, the total development of five cavities and their subdivisions was observed. It also was observed the presence of an equal and continuous spinal cord with the

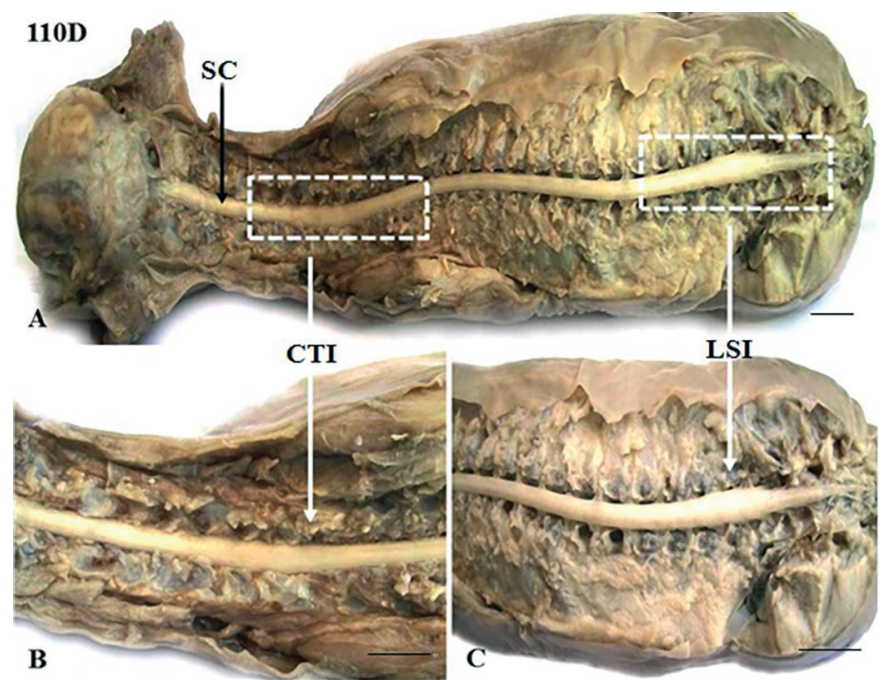

Fig.5. Bovine fetus trunk at 110 days in dorsal view. (A) Spinal cord (SC). (B) Cervicothoracic tumescence (CTI) and (C) Lumbosacral tumescence (LSI). Bars $1 \mathrm{~cm}$. 
cervicothoracic and lumbosacral tumescence different periods of pregnancy. No difference to the disposition of the spinal cord for each bovine fetus was observed. The origins of the spinal nerves were perpendicular $\left(90^{\circ}\right)$ of spinal cord (Fig.5).

The primitive spinal cord originated from the caudal portion of the neural tube was composed of a thick neuroepithelium. Under the neuroepithelium, a layer of loose connective tissue was observed. We were able to notice the mesenchyme lining the neural tube, which compose the primitive meninges; a thick membrane which forms the dura mater, and its thin internal surface, which remains and constitutes the leptomeninx composed by the arachnoid mater and pia mater.

\section{DISCUSSION}

The nervous system is particularly interesting for the morphologist for being the most complex of the body, even if it is conservative regarding to changes. Comparative and developmental studies enable morphologist to build sketches of phylogenetic, especially of this system. From the nervous system, it is possible to determine accurately, for example, the general habits of an animal (in cases where the information is suitable). Thus, by adding knowledge about the macroscopy, microscopy and ultrastructure of this system that the morphologist is able to give its biggest contribution in applied sciences. The nervous system is a very active field of research (Hildebrand \& Goslow 2006, Silva et al. 2016). Then, in present studies, detailed data were found and might be useful for future researches on the CNS.

By 18 days of gestation, the bovine embryos are present in the gastrula, with formation of amnion and primitive line, which is characterized by converting the bilaminar germ disc in three layers: ectoderm, mesoderm and endoderm. In our study, we observe the somites and the neural tube from the 17 days of pregnancy. Evans \& Sack (1973) described only at 19 days occurs the first somites of the folding of the neural plate. Already Maddox-Hyttel et al. (2007) describe that 21 days embryos, feature a primitive line extended towards the cranial pole, however, without neural tube development.

According to Winters et al. (1942), at 22 days and 16 hours of gestation, bovine embryos exhibit the neural canal completely closed and 19 pairs of somites and the cephalic region set. Until the 24th day of gestation, before implantation period, the embryo undergoes significant growth and cellular differentiation, following the uterine tubes (fallopian tubes) to the uterus for implantation. The author describes that from 24 th to 26 th, three encephalic vesicles become visible, but in our study after 24 days of gestation have been observed the five encephalic vesicles.

The neurological system in the cattle embryo found in our study follows the pattern of differentiation that found in Buffalo, where Morini (2009) describes the CNS arises from the neural plate and subsequently the neural tube of ectodermal origin. With the growth of the embryo, during pregnancy, there are three encephalic vesicles, called: prosencephalon, mesencephalon and rhombencephalon (Sinowatz 2010, Franciolli et al. 2011).
Table 2. Tertiary division of the neural tube and the relationship of the their main structures and lumen, in fetuses at 90 days

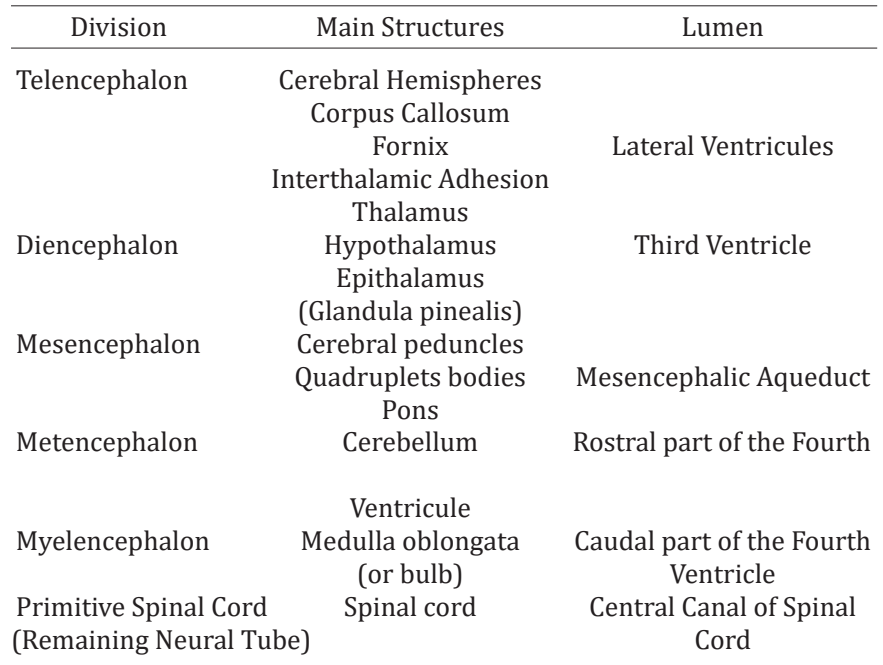

The subdivisions of the neural tube and later of five encephalic vesicles found in our study follows the one described for animals domestic mammals described by Sinowatz (2010) and also those described in humans (Moore \& Persaud 2004). Table 2 illustrates these events of differentiation and derivation of the neural tube and the encephalic vesicles.

The present study found detailed results in CNS embryology in cattle from 17 days, until late pregnancy. As demonstrated, the CNS has a complex system of anatomical and tissue differentiation. Therefore, subdivisions of embryonic neural plate and neural tube that will form the CNS require a deeper understanding that can describe the molecular and cellular mechanisms that determine the successive developments and tissue derivation, giving rise to a complex system of encephalic vesicles. The detailed embryology of the CNS was described in this study, thus other studies can further search for teratogenic factors (Evans \& Sack 1973), which affect the CNS in cattle during pregnancy.

As follows, the thorough anatomical knowledge and raised tissue in this study, if associated with molecular biology techniques may assist in the discovery of the mechanisms involved in CNS abnormalities, also it can provide support to pharmaceuticals formulation and prophylaxis of different neurological pathologies and dysfunctions that affect cattle herds and generate economic losses as described by Rissi et al. (2010) and Melz et al. (2014). Furthermore, currently, studies about embryology of the CNS have received more attention due to microcephaly outbreak, which is characterized by malformation of the central nervous system, caused by Zika virus (Cugola et al. 2016).

However, this study showed that a 17 days bovine embryo presents neural tube formation, cranial neuropore, caudal neuropore and somites training. After 24 days it was observed the five encephalic vesicles: telencephalon, diencephalon, mesencephalon, metencephalon and myelencephalon; and the neural tube is continued caudally by primitive spinal cord. The 90 days is the differentiation of primary CNS regions. It can be observed the cavity of pri- 
mitive spinal cord, the central canal of spinal cord, and the ventricular system (lateral ventricles, third ventricle, mesencephalic aqueduct, fourth ventricle and central canal of the spinal cord). The main structures were identified: (1) cerebral hemispheres, corpus callosum and fornix, of the telencephalon; (2) interthalamic adhesion, thalamus, hypothalamus and epythalamus (glandula pinealis), of the diencephalon; (3) cerebral peduncles and quadruplets bodies, of the mesencephalon; (4) pons and cerebellum, of the metencephalon; (5) medulla oblongata or bulb, of the myelencephalon; and (6) spinal cord, of the primitive spinal cord. After 110 days, until the end of the pregnancy, the five encephalic vesicles and its structures are completely developed. Also was noted the presence of the spinal cord with the cervicothoracic and lumbosacral intumescences. In addition, the origins of the spinal nerves were perpendicular $\left(90^{\circ}\right)$ of spinal cord, showing the symmetric growth of nervous system and vertebral column (Prada 2014).

\section{CONCLUSIONS}

The present study described the formation of the neural tube from the neural plate of the ectoderm and the encephalic vesicles derived from the neural tube and, subsequently, the structures formed of each of these vesicles, further the primitive spinal cord, thus constituting the complete embryology of the central nervous system.

These data provide new knowledge related to a normal development and may be useful for CNS abnormalities studies.

Acknowledgements.- Thanks are due to CAPES (Coordenação de Aperfeiçoamento de Pessoal de Nível Superior) for funding the project.

\section{REFERENCES}

Arthur G.H. 1979. Reprodução e Obstetrícia em Veterinária. 4ª ed. Ganabara Koogan, Rio de Janeiro.

Cagnoto D.G., Guerra R.R., Alberto M.V., Ambrósio C.E., Santos E.J.M. \& Miglino M.A. 2009. Morfologia e desenvolvimento ultraestrutural do sistema renal de embriões bovinos com idade gestacional entre 10 e 50 dias. Ciência Rural 39:2154-2161.

Cugola F.R., Fernandes I.R., Russo F.B., Freitas B.C., Dias J.L.M., Guimarães K.P., Benazzato C., Almeida N., Pignatari G.C., Romero S., Polonio C.M., Cunha I., Freitas C.L., Brandão W.N., Rossato C., Andrade D., Faria D.P.,
Garcez A.T., Buchpigel C.A., Braconi C.T., Mendes E., Sall A.A., Zanotto P.M.A., Peron J.P.S., Muotri A.S. \& Beltrão-Braga P.C.B. 2016. Nature 534:267-271.

Evans H.E. \& Sack W.O. 1973. Prenatal development of domestic and laboratory mammals: growth curves, external features and selected references. Anat. Histol. Embriol. 2:11-45.

Franciolli A.L.R., Ambrósio C.E., Oliveira M.F., Morini A.C., Favaron P.O., Machado M.R.F. \& Miglino M.A. 2011. Os histricomorfos sul-americanos: uma análise comparativa do desenvolvimento embriológico. Pesq. Vet. Bras. 31:441-446.

Greene N.D. \& Copp A.J. 2009. O desenvolvimento do sistema nervoso central dos vertebrados: a formação do tubo neural. Prenatal Diagnosis 29:303-311.

Hildebrand M. \& Gowlow G.E. 2006. Análise da Estrutura dos Vertebrados. $2^{\mathrm{a}}$ ed. Atheneu, São Paulo.

Maddox-Hyttel P., Wolf X.A., Rasmussen M.A. \& Schauser K. 2007. Embryonic stem cells in pig and cattle: Derivation, culture and potential applications. Acta Sci. Vet. 35:823-830.

Melz L.J., Marion-Filho P.J., Bender-Filho R. \& Gastardelo T.A.R. 2014. Determinantes da Demanda Internacional de Carne Bovina Brasileira: evidências de quebras estruturais. Revta Economia Sociologia Rural 52(4):743-760.

Moore K.L. \& Persaud T.V.N. 2004. Embriologia Clínica. 6aa ed. Guanabara Koogan, Rio de Janeiro.

Morini A.C. 2009. Desenvolvimento embrionário em búfalo (Bubalus bubalis Linnaeus, 1758). Dissertação de Mestrado em Anatomia dos Animais, Faculdade de Medicina Veterinária e Zootecnia, Universidade de São Paulo, São Paulo.

Noden D.M. \& De Lahunta A. 1990. Embriologia de los animales domésticos. Acríbia, Zaragoza.

Prada I. 2014. Neuroanatomia Funcional em Medicina Veterinária com Correlações Clínicas. Editora Terra Molhada, Jaboticabal.

Rexroad C.E., Casida L.E. \& Tyler W.J.M. 1974. Crown-rump length of fetuses in purebred Holstein-Friesian cows. J. Dairy Sci. 57:346-347.

Rissi D.R., Pierezan F., Oliveira-Filho J.C., Lucena R.B., Carmo P.M.S. \& Barros C.S.L. 2010. Abordagem diagnóstica das principais doenças do sistema nervoso de ruminantes e equinos no Brasil. Pesq. Vet. Bras. 30:958967.

Silva F.M.O., Alcântara D., Carvalho R.C., Favaron P.O., Santos A.C., Viana D.C. \& Miglino M.A. 2016. Development of the central nervous system in guinea pig (Cavia porcellus, Rodentia, Caviidae). Pesq. Vet. Bras. 36:753760.

Sinowatz F. 2010. Development of the central and peripheral nervous system. In: Hyttel P., Sinowatz F. \& Vejlsted M. (Eds), Essential of Domestic Animal Embriology. Elsevier, China.

Winters L.M., Green W.W. \& Comstock R.E. 1942. Prenatal development of the bovine. Agric. Exp. Station Tech. Bull. 151:1-50. 